\title{
Case Study on the Adaptive Teaching Mechanism of Subject Teacher Educators Under the Background of New Normal
}

\author{
Yaqi Zhang ${ }^{1, *}$ \\ ${ }^{1}$ School of Education, Northwest Normal University, Lanzhou, Gansu 730070, China \\ *Corresponding author.2018103027@nwnu.edu.cn
}

\begin{abstract}
Based on the background of new normal education, this study tries to explore the internal mechanism of the adaptive teaching process of subject teacher educators. Using the methods of questionnaire, observation and interview, this paper systematically analyzes the adaptive teaching mechanism of 428 students and 8 subject teacher educators in N Normal University. It is found that the process of adaptive teaching revolves around the "six elements", and the interaction between the six elements is reflected in the reflective practice process of subject teacher educators to adapt to the different needs of students. The innovation of this study is reflected in the attention to the adaptive teaching mechanism of subject teacher educators.
\end{abstract}

Keywords: subject teacher educators, adaptive teaching mechanism, six elements, epistemology of reflective

practice

\section{INTRODUCTION}

The Opinions of the CPC Central Committee and The State Council on Comprehensively Deepening the Reform of Teacher Staff Construction in the New Era was issued in January 2018, marking a significant turn from China's teacher education reform to normal education. Such a change has brought a great impact on the subject teacher educators who undertake the course of subject pedagogy.

Adaptive teaching mechanism[1] refers to the teaching process in which teachers adopt unconventional, creative and differentiated teaching strategies to promote students' personalized development through the reflection in response to students' personalized needs and the interaction between various elements in the teaching process. At present, the research on the teaching practice of subject teacher educators focuses more on practical strategies than on the adaptive teaching mechanism.[2][3] The relevant research of adaptive teaching practice also does not pay attention to the special group of subject teacher educators. Therefore, based on the dialectical analysis of Schon's epistemology of reflective practice[4], this study constructed the adaptive teaching process of subject teacher educators as a six-element model as shown in Figure 1, including student performance, adaptive teaching strategies, adaptive teaching effect testing, personal belief support system, external support system, reflection and other elements.

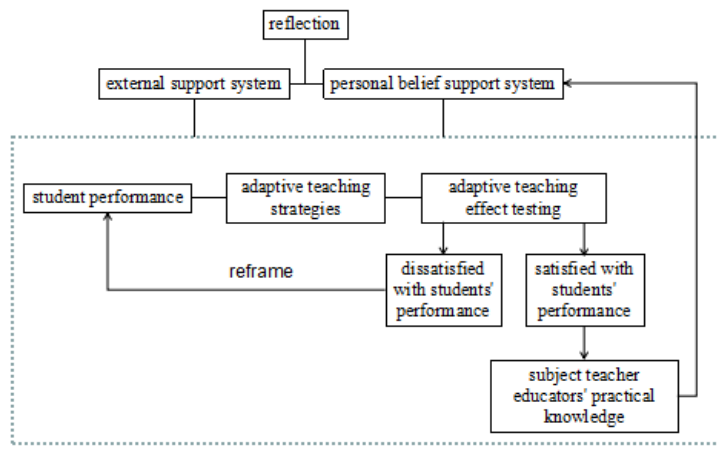

Figure 1 Six-Element Model of Subject Teacher Educators Teaching Process

\section{PROBLEMS AND METHODOLOGY}

This study mainly discusses the following two questions: first, what are the common characteristics of the elements of the teaching activity mechanism of subject teacher educators? Second, how do these elements work in the teaching process of subject teacher educators?

The research adopts the mixed research method, selects $\mathrm{N}$ Normal University in a city of G Province as a case, and collects data by means of questionnaire, interview and participatory observation. This study adopts the "purposive sampling" method to determine the subject teacher educators of $\mathrm{N}$ Normal University as the research object. To determine $\mathrm{N}$ Normal University as a research field, a reform in 2018 is mainly considered. N Normal University carried out the reform of "new normal" education innovation action plan. The basic idea of this reform is 
more concerned with the cultivation of normal students' educational and teaching practical ability.

The research objects of the questionnaire survey are 428 students from the class taught by eight subject teacher educators. A total of 428 questionnaires of Satisfaction with the Teaching of Subject Teacher Educators are distributed, 428 of which are recovered, and the effective recovery rate is $100 \%$. The scale of Satisfaction with the Teaching of Subject Teacher Educators investigates the normal students' satisfaction with subject teacher educators' teaching from five dimensions: curriculum design of subject teacher educators, teaching purpose of subject teacher educators, teaching methods of subject teacher educators, teaching contents of subject teacher educators, and teaching evaluation of subject teacher educators. There are 15 questions in the subject teacher educators' satisfaction with teaching scale. The questions of the scale are answered by Likert's five-point scoring system, and assigned 1 to 5 from low to high. Cronbach Salpha coefficient is used to test the internal consistency reliability of 15 questions in five dimensions of the questionnaire. The results show that the alpha coefficient of the internal consistency of the questionnaire is 0.89 , which shows that the reliability of the questionnaire is good.

The interviewees are selected by "sampling within a case". Eight subject teacher educators are selected as the main interviewees from 15 subject teacher educators in the Institute of Education. In addition to interviews, this study conducts participatory observation on 8 teachers' classroom teaching, mainly to observe how they conduct classroom teaching. In terms of data sorting and analysis, all interview data and observation data are transcribed into text content. The types of data sources are represented by I and $\mathrm{O}$ respectively. The way of data naming is "provider plus teaching subject plus data source plus date", in which "provider" is named after the initials of the research object's name.

\section{RESULTS}

The teaching process of subject teacher educators in $\mathrm{N}$ Normal University relies on the research framework of "six elements" and the survey results of students' Satisfaction with the Teaching of Subject Teacher Educators. The analysis is based on Curriculum Standards and Teaching Materials Research in Middle School and Subject Curriculum and Teaching (Experimental) Design in Middle School.

\subsection{Analysis of the Current Situation of Students' Satisfaction with Subject Teacher Educators}

\subsubsection{Students' Satisfaction with the Curriculum}

Students hold a positive attitude towards the courses offered, and the average recognition of the importance of the two courses, namely, Curriculum Standards and Teaching Materials Research in Middle School and Subject Curriculum and Teaching (Experimental) Design in Middle School, are 4.07 and 4.02 respectively, which are higher than the median value of 3 , indicating that students think that setting up these two courses is more important for students' learning and development (as shown in Table 1).

Table 1 Average and Standard Deviation of the Evaluation of the Importance of Curriculum Offered by Normal Students

\begin{tabular}{|c|c|c|}
\hline Course & M & SD \\
\hline $\begin{array}{c}\text { Curriculum Standards and } \\
\text { Teaching Materials Research } \\
\text { in Middle School }\end{array}$ & 4.07 & 0.88 \\
\hline $\begin{array}{c}\text { Subject Curriculum and } \\
\text { Teaching (Experimental) } \\
\text { Design in Middle School }\end{array}$ & 4.02 & 0.91 \\
\hline
\end{tabular}

\subsubsection{Students' Satisfaction with Teaching Methods}

The investigation on the application of the teaching methods of the teachers of the two courses shows that the teaching methods used by the teachers of Curriculum Standards and Teaching Materials Research in Middle School are mainly teaching and demonstration, with the average values of 3.95 and 3.77 respectively; the teaching methods of the teachers of Subject Curriculum and Teaching (Experimental) Design in Middle School are mainly teaching, group cooperative learning and demonstration teaching, with the average value of 3.81 , 3.79 and 3.72 respectively (as shown in Table 2 ). 
Table 2 Average and Standard Deviation of Teachers' Teaching Methods

\begin{tabular}{|c|c|c|c|}
\hline & Indicator & $M$ & $S D$ \\
\hline \multirow{5}{*}{$\begin{array}{l}\text { Curriculum Standards and Teaching } \\
\text { Materials Research in Middle School }\end{array}$} & lecturing & 3.95 & 0.64 \\
\hline & demonstration & 3.77 & 0.68 \\
\hline & individual practice & 3.58 & 0.73 \\
\hline & group discussion & 3.76 & 0.76 \\
\hline & case study & 3.67 & 0.76 \\
\hline \multirow{7}{*}{$\begin{array}{c}\text { Subject Curriculum and Teaching } \\
\text { (Experimental) Design in Middle School }\end{array}$} & individual inquiry learning & 3.66 & 0.73 \\
\hline & group cooperative learning & 3.79 & 0.73 \\
\hline & case study & 3.65 & 0.69 \\
\hline & literature reading & 3.47 & 0.80 \\
\hline & classroom simulation & 3.40 & 0.81 \\
\hline & lecturing & 3.81 & 0.65 \\
\hline & demonstration & 3.72 & 0.67 \\
\hline
\end{tabular}

\subsubsection{Students' Satisfaction with Teachers' Teaching Evaluation}

According to the survey of students' satisfaction with teachers' teaching evaluation, it is found that the average value of fairness and appropriateness of teachers' teaching evaluation is 4.08 , which is most recognized by students, but slightly disapproved of the diversity of teaching evaluation. The average value of this index is 3.99 (as shown in Table 3).

Table 3 Average and Standard Deviation of Teachers' Teaching Evaluation

\begin{tabular}{|c|c|c|}
\hline Indicator & $\boldsymbol{M}$ & $\boldsymbol{S D}$ \\
\hline value & 4.03 & 0.59 \\
\hline fairness and properness & 4.08 & 0.57 \\
\hline $\begin{array}{c}\text { diversified evaluation } \\
\text { methods }\end{array}$ & 3.99 & 0.65 \\
\hline process evaluation & 4.01 & 0.62 \\
\hline
\end{tabular}

\subsection{Adaptive Teaching Process of Subject Teacher Educators}

Based on the above survey on the satisfaction of subject teacher educators, it is found that the teaching methods of teachers mostly adopt methods including teaching and demonstration, which may be affected by the nature and objectives of the two courses. In addition, the teaching method is not necessarily the pronoun of inefficient teaching methods. If the teaching is carried out with normal students as the center, then the teaching of teachers is also successful. The following is to explore the mechanism of teachers' teaching process through participatory observation and interview.

\subsubsection{Students' Performance}

Students' performance mainly focuses on two aspects, namely normal students' learning performance and learning motivation. Teacher L, who is responsible for the teaching task of Physics Curriculum Standards and Teaching Materials Research in Middle School, found that "in the physics textbook of junior high school, it talks about the straight-line propagation of light. At the beginning, it is said that in foggy weather, you can see that the light travels along a straight line. Then you ask normal students why it is foggy weather? He doesn't know" (L-WL-I-0909). Furthermore, the learning motivation of normal students is also the basis of the next link organized by subject teachers and educators. W, a teacher of Mathematics Curriculum Standards and Teaching Materials Research in Middle School, finds that students' learning motivation is not strong, and it mainly because of two reasons: "now there are more and more students taking postgraduate entrance examination, they don't want to be teachers, so they think it's useless to learn this course" (W-SX-I-0708).

\subsubsection{Adaptive Teaching Strategies}

There are two types of adaptive teaching strategies for subject teacher educators, such as the implicit demonstration of examples and the inquiry of questions. For the L teacher, when explaining how to implement the curriculum concept of value education into the classroom teaching of primary and secondary school students, he/she needs to have some basic strategies (L-SZ-O-1103) to demonstrate the theme of "teacher-student interaction" for normal students through examples of teaching strategies. There are also teachers, through questions and continue to ask questions and other ways, to explore normal students' mastery of knowledge, and promote their in-depth understanding.

Teacher L: put the alarm clock in the glass cover to remove the air, and the sound becomes smaller? What is the purpose of this experiment?

Students: it explains that communication needs media.

Teacher L: Well, you should pay attention to this. Put the alarm clock in the glass cover, and the sound will become smaller after the air is removed. Can the sound be completely absent?

(waiting for students to answer) 
Teacher L: it can't be completely absent, because the air can't be completely evacuated "(L-WL-O-0915).

\subsubsection{Adaptive Teaching Effect Testing}

When teacher $\mathrm{S}$ adopts the strategy of questioning, the students do not give an answer. Teacher $\mathrm{S}$ reflects that the students may not understand what the teacher is asking, so he/she changes the way of asking, and finally gets a satisfactory answer.

Teacher S: I cite a detail described in the article Lao Wang, "one evening, we were walking through a remote alley and saw a dilapidated courtyard with several dilapidated cottages. Lao Wang was riding his tricycle into it. Later I asked Lao Wang, is that his home?" Do you remember what Lao Wang said?

(Silence)

Teacher S: "Lao Wang said that he has lived there for a long time". What special things do you feel from this question and answer?

\section{(Silence)}

Teacher S: he said he had lived for a long time, but he didn't mention that this is his home. What does it mean?

Students: he doesn't have a real home.

Teacher S: Yes, that's what the author is brilliant about. It seems very plain, but it has written a lot of about the biggest pain in the heart inadvertently, right? Because the author asked, "is that your home?" Laowang gave an irrelevant answer, just said he has lived there for a long time. (S-YW-O-0914)

\subsubsection{Personal Belief Support System}

Teachers' beliefs affect teachers' behavior. [5] Belief is a cognitive tool for framing and defining phenomena [6] and it consists of a cognitive component that represents knowledge, an emotional component that evokes emotion, and an active behavioral component in action. W, the teacher of Subject Curriculum and Experimental Design in Middle School, holds that the experimental design course is to make normal students understand "true physics and understand the truth", and "true physics is that only when students see the scene can they understand the principles of physics. When you tell him how powerful internal energy is and how much work he has done, he does not have this concept. Therefore, it is important to see the phenomena. Physics is not only a matter of looking, but also the reason for understanding. This principle, including the understanding of rationality, is to rise from sensibility to rationality"(W-WL-I-0623).

\subsubsection{External Support System}

All the case teachers said that teachers' professional learning and training is the turning point of their teaching transformation. Just as the teacher $\mathrm{Z}$ studied comparative literature during his postgraduate period, his experience in pursuing a doctorate and a postdoctoral degree has realized the leap and integration of disciplinary discourse system and pedagogy discourse system. "The discourse framework of Chinese language and literature is different from that of subject teaching method. Therefore, in the past few years, he began to cross major, and the process of transformation is a challenge"'(Z-YW-I-0708). Although the teacher W studied mathematics curriculum and teaching theory major during the graduate period, he did not encounter the conflict between two sets of discourse systems, but his on-job training made him contact with participative teaching for the first time. He changed his focus from how to teach himself to how do students learn, and realized the student-centered teaching.

\subsubsection{Reflection}

The reflection of subject teacher educators is reflexive, which promotes the change of personal cognition and behavior. Its path is reflection, introspection and resolved action for empirical cognition. [7]Teacher educators reflect on their own teaching, which is the examination of "how to teach". After a class, the teacher L finds that the teaching content is not comprehensive, and the teaching plan needs to be adjusted. In fact, the reflection on the teaching content is that you are in the middle of the teaching process. After the first class, you will find that there are some places that you did not consider comprehensively at the beginning of the design. The teacher $\mathrm{L}$ may want to adjust the teaching plan in the next class, which is for sure" (L-WL-I-1124).

\section{DISCUSSION}

\subsection{Common Elements of Adaptive Teaching Process of Subject Teacher Educators}

The common elements in the teaching process of subject teacher educators are shown in Table 4. By combing and analyzing the common elements in the teaching process, it is found that teacher teaching in $\mathrm{N}$ normal university belongs to the teaching under the mode of intermediary process. The teaching not only pays attention to teachers' teaching behavior, but also concerns the thinking process behind it. 
Table 4 Common Elements of Subject Teacher Educators' Teaching Process

\begin{tabular}{|l|l|}
\hline \multicolumn{1}{|c|}{ Dimension } & \multicolumn{1}{c|}{ Element } \\
\hline Students' performance & Normal students' learning performance and learning motivation \\
\hline $\begin{array}{l}\text { Adaptive teaching } \\
\text { strategy }\end{array}$ & An implicit demonstration of examples; inquiry of questions \\
\hline $\begin{array}{l}\text { Adaptive teaching effect } \\
\text { testing }\end{array}$ & $\begin{array}{l}\text { If satisfied with the teaching results, practical knowledge is formed; if not } \\
\text { satisfied with the teaching results, problems should be redefined, students } \\
\text { performance should be examined and teaching strategies should be } \\
\text { re-selected }\end{array}$ \\
\hline $\begin{array}{l}\text { Personal belief support } \\
\text { system }\end{array}$ & Views on the subject; views on teaching \\
\hline External support system & Study for a degree; professional training \\
\hline Reflection & Reflexivity \\
\hline
\end{tabular}

\subsection{Operation Process of Subject Teacher Educators' Adaptive Teaching Mechanism}

Adaptive teaching is a kind of teaching centered on normal students. First of all, based on the students' cognitive schema, interest, knowledge base, ability level and learning process, the individual teaching is debugged. Secondly, the test of teaching effect is the dialogue between teachers and situations. Through the dialogue with situations, teachers' personal cognition is clear, and teachers' accurate positioning and grasp of students' needs are helpful. Thirdly, the whole adaptive teaching process is supported by personal belief system and external support system. Finally, teacher reflection plays the most important role and function. Only when teacher educators are good at reflecting and reflecting on themselves can they effectively use the personal belief support system and external support system to promote the operation of the whole adaptive teaching process.

\section{CONCLUSION}

In a word, the teaching mechanism of subject teacher educators includes two parts: one is the teaching process, which revolves around the "six elements" process framework. The second is the relationship between the elements in the teaching process, which is the embodiment of the intermediary process-oriented teaching.

\section{REFERENCES}

[1] S.A. Parsons, M. Vaughn, R.Q. Scales, "Teachers' Instructional Adaptations: a Research Synthesis," Review of Educational Research, vol. 2, pp. 205-242,
April 2018. DOI:

https://doi.org/10.3102/0034654317743198.

[2] B. Juarez, "The Intersection of Theory and Practice in Teacher Preparation Course," Journal of Instructional Research," vol. 8, pp. 84-88, 2019.

DOI:https://eric.ed.gov/contentdelivery/servlet/ERICSer vlet?accno=EJ1242592

[3] M. Lunenberg, F. Korthagen, A. Swennen, "The Teacher Educator as a Role Model," Teaching and Teacher Education, vol. 23, pp. 586-601, July 2007. DOI: https://doi.org/10.1016/j.tate.2006.11.001

[4] Schon D. A, The Reflective Practitioner: How Professionals Think in Action. New York: Basic books, 1983.

[5] Fred A.J. Korthagen, "In Search of the Essence of a Good Teacher: Towards a More Holistic Approach in Teacher Education," Teaching and Teacher Education, vol. 20, pp. 78-81, January 2004. DOI: https://doi.org/10.1016/j.tate.2003.10.002

[6] M. Frank Pajares, “Teachers' Beliefs and Educational Research: Cleaning Up a Messy Construct," Review of Educational Research, vol. 62, pp. 321, September 1992. DOI: https://doi.org/10.3102/00346543062003307

[7] J. Lunn Brownlee, L.E. Ferguson, M. Ryan, "Changing Teachers' Epistemic Cognition: a New Conceptual Framework for Epistemic Reflexivity," Educational Psychologist, vol. 4, pp. 242-252, June 2017. DOI: https://doi.org/10.1080/00461520.2017.1333430 